\title{
Minority Rights in Croatia - From Independence of Croatia until 2010
}

\author{
Goran Bandov*
}

\begin{abstract}
The aim of this paper is to present the protection of minority rights in Croatia from independence until 2010, the most important challenges in the process and the problems facing the implementation of legal solutions. From the time of independence until recently the Republic of Croatia has passed through a turbulent period of ethnic and political strains. All cases of European integration were conditioned by the implementation of measures of minority protection, especially with concerns to the Serbian national minority. Croatia fulfilled the challenges in the 1990s primarily due to political pressure. A different approach followed democratic changes in 2000. The most radical breakthrough was the Constitutional Law on the Rights of Minorities in 2002, which regulated the protection of minorities in a proper way. Its implementation was not completely satisfactory, especially at local and regional levels. But after pressures from the central government after 2008, there have been no major flaws in implementing minority rights in the Republic of Croatia.
\end{abstract}

Keywords: Croatia, minority rights, norm implementation Kroatien, Minderheitenrechte, Normimplementierung

\section{Protection of Minorities from Independence of Croatia until 2000}

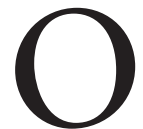
$\mathrm{n}$ the mark of independence Croatia was faced with difficult challenges. One of them concerned their minority legislation, which was not always successful. The 1990 constitution offered a very fragile protection of minorities rights, which was very dangerous due to potential ethnic and political escalation. The international community rejected the constitutional decision as not being democratic enough, believing that it could not fulfill the high standards of protection of ethnic and national minorities. ${ }^{1}$ As a result, the Arbitration Commission of the Peace Conference on the Former Yugoslavia (commonly known as Badinter Arbitration Committee) asked that improvement of minority protection be made a prerequisite for an international acknowledgment of the Republic of Croatia. This resulted in the „Charter of the Rights of Serbs and Other Nationalities in the Republic of Croatia“ (1991) and the „Constitutional Law on Human Rights and Freedoms of National and Ethnic Communities in the Republic of Croatia“ (1991), which was going to be constantly amended and corrected in the following period. ${ }^{2}$

Due to pressure form the international community the Constitutional Law on National Minorities (1992) was established to protect the countries minorities. ${ }^{3}$ It envisages

* Goran Bandov is Assistant Professor of International Relations at the University College of International Relations and Diplomacy, Zagreb, Croatia, E-mail: goran.bandov@diplomacija.hr. This article has successfully undergone a double-blind peer-review process.

1 Žagar, Mitja: Noviji trendovi razvoja zaštite manjina i (posebnih) prava nacionalnih i drugih manjina, p. 17, in: Obradović, Stojan /Tatalović, Siniša (edit.): Nacionalne manjine I, STINA, Split, 2003; Gjenero, Davor: Manjinsko biračko pravo u Hrvatskoj - pregled iskustava od 1992 do 2003, p.32, in: Obradović, Stojan /Tatalović, Siniša (edit.): Nacionalne manjine II, STINA, Split, 2005

2 The Charter on the Rights of Serbs and Other Nationalities in the Republic of Croatia, Official Gazette 31/91; The Constitutional Law on Human Rights and Freedoms of National and Ethnic Communities in the Republic of Croatia, Official Gazette 65/91; Constitutional Laws on minority rights after 1991: Official Gazette 27/92, 34/92, 51/00, 105/00, 155/02.

3 The Constitutional Law on Human Rights and Freedoms of National and Ethnic Communities in the Republic of Croatia, Official Gazette 34/92. autonomous regions for Knin and Glina that had a majority Serb population. ${ }^{4}$ This would enable participation of minority groups in all levels of government, as long as the minority group consisited of $8 \%$ of the total population, which meant that at the time the Serbian minority benefitted from this. After 1995 all stipulations of the Constitutional Law were suspended because not one minority fulfilled the criteria. Stipulations about autonomous regions for Knin and Glina were also suspended although they had never taken effect. In all later versions of Constitutional Laws there has been no mention concerning minority rights; there also has been no real need for it because not a single minority lives exclusively on a limited area.

\section{Reforms in Croatian Society after $\mathbf{2 0 0 0}$}

The 1990s marked the Croatian political scene through the prism of an ethno-political conflict, with the the dominant President Franjo Tuđman and the ruling Croatian Democratic Union (HDZ) causing much tension. The result was a constantly strained relationship with the international community. In 2000, a left-center and liberal coalition declared victory, initiating reconstruction of society and strong reforms, including for stronger instruments of minority legislation. Only a few months later, the new coalition adopted a new Constitutional Law (2000), which was actually only a better version of previous legal solutions. ${ }^{5}$ However, the coalition itself was not very satisfied with the solution and promised to establish completely new instruments and institutions for minority protection in a short period of time. ${ }^{6}$

4 Marko, Joseph / Geistlinger, Michael: Minderheitenschutz im östlichen Europa - Kroatien, Forschungsprojekt des Instituts für Ostrecht der Universität Köln, 2005, p. 6

http://www.uni-koeln.de/jur-fak/ostrecht/minderheitenschutz/Vortraege/ Kroatien/Kroatien_Marco_Geistlinger.doc (12.04.2011).

5 The Constitutional Law on Human Rights and Freedoms of National and Ethnic Communities in the Republic of Croatia, Official Gazette 51/00.

6 International Helsinki Federation for Human Rights, The Report 2001, p. 104. 
On the same day, implementation laws were passed that regulated two specific fields of cultural autonomy of minorities: the right to minority education in the language and script of the minority and the right to the free use of minority languages and scripts. ${ }^{7}$ These legal solutions were of the highest quality but had two major flaws. The first one concerned a very narrow spectrum of protection that the laws covered. The second concerned the implementation being left to local and regional self-government. Both authorities opposed implementation of legal norms and skillfully obstructed the central government.

New reforms specifically introduced a number of new national minorities in the Preamble of the Constitution of the Republic of Croatia (2001), which resulted in a major contribution in the process of further strengthening the status of minority communities: “... the Republic of Croatia is hereby established as the national state of the Croatian people and a state of members of other nations and minorities who are its citizens: Serbs, Muslims, Slovenes, Czechs, Slovaks, Italians, Hungarians, Jews and others, who are guaranteed equality with citizens of Croatian nationality and the realization of ethnic rights in accordance with the democratic norms of the United Nations and countries of free world." 8

\section{Realization of Minority Protection in Accordance with a Constitutional Legal Solution in 2002}

In 2002 Croatia made the largest step in improving legal regulations that covered minority rights by enforcing the Constitutional Law on the Rights of National Minorities (2002). ${ }^{9}$ The step was actually incited by obligations that Croatia accepts in "The Stabilization and Association Process with the European Union", but also by the real political will existing in the political coalition then. ${ }^{10}$ It was highly detailed in covering overall issues of protection of minorities, and it covered all four levels of minority protection (fundamental, cultural, political and socioeconomic levels). Since 2002, Croatia has not established any new constitutional or legal regulations in connection with minority rights. Actually, there is no need for them. The challenges lie primarily in the implementation of positive regulations envisaged by the Constitutional Law (2002).

\subsection{Fundamental Level of Minority Protection}

The fundamental level of minority protection is the most important level. Without its realization there is not a single freedom or right based on minority affiliation. It is primarily connected to acknowledgment of a legal minority status

7 The Law on Education in Languages and Scripts of National Minorities, Official Gazette 51/00, 56/00; The Law on the Use of Languages and Scripts of National Minorities, Official Gazette 51/00, 56/00.

8 The Constitution of Republic of Croatia, Official Gazette 41/01, 55/01, Preamble.

9 The Constitutional Law on the Rights of National Minorities, Official Gazette $155 / 02$.

10 Tatalović, Siniša: Mjerilo demokratizacije društva, p. 17, in: Malović, Stjepan (edit.): Bogatstvo različitosti, Sveučilišna knjižara, ICEJ, OSCE, Zagreb, 2004. to a group by giving collective rights to an entire minority community. Prior to Croatia gaining independence, protections were granted to Hungarian, Italian, Czech, Slovakian, Ruthenian and Ukrainian minority groups. After independence Croatia recognized the legal status of the following ethnic and national minority groups: Albanians, Austrians, Bosniacs, Bulgarians, Czechs, Germans, Greeks, Hungarians, Italians, Jews, Macedonians, Montenegrins, Muslims, Polish, Roma, Romanians, Russians, Ruthenians, Serbs, Slovaks, Slovenes, Turks, Ukrainians and Vlachs. ${ }^{11}$ According to the census in 2001, the most numerous group were the Serbs with 201,631 members, and the least was the Vlach minority with only 12 members. ${ }^{12}$ The example of the Vlachs, but also some other minorities such as Austrians, Bulgarians, Jews, Poles, Romanians and Turks, who according to the census have less than $0.01 \%$ members in Croatia, clearly shows the political willingness to grant minority status as a condition for realization of other levels of minority rights, but also a condition for preventing assimilation.

Because of the lifestyle and conditions of the Roma minority, there is still a significant amount of discrimination against them. In order to further improve living conditions for the Roma minority, the government adopted a National Programme for Roma in October 2003. In 2005 Croatia participated with several other European countries in the 'Decade of Roma Inclusion 2005-2015'. The goal was a collaboration of Europe's largest countries to help facilitate the poorest and most discriminated European minority by focusing on re-building education, health care, employment and housing, and also improving the living conditions. ${ }^{13}$ A significant step occurred within the Roma community when Mr. Nazif Memedi was elected into the Croatian Parliament as a Roma representative ${ }^{14}$ during the last parliamentary elections held in 2007.

\subsection{Cultural Level of Minority Protection}

The basis of the cultural level of minority protection is the free use of language and script of minorities, meticulously elaborated in the law about the free use of language and script for the education of minorities. ${ }^{15}$ The much wider spectrum of protection of cultural identity is guaranteed by the Constitutional Law (2002), which lists in detail instruments that regulate the free use of minority language and script and efficacious protection of the cultural identity of minority

11 Data provided by the Central Bureau of Statistics - data on the number of members of national minorities in Croatia. http://www.dzs.hr.

12 Data provided by the Central Bureau of Statistics - data on the number of members of national minorities in Croatia. http://www.dzs.hr.

13 Through its pre-accession PHARE and IPA programs, the EU allocated 4 million euros for the achievement of the Decade's main goals in Croatia. The European Parliament: Protection of the Roma in Croatia, Report, October 2010, p. 1.

14 At the Croatian parliamentary elections held on 25 November 2007, a representative of the Roma community has been elected as a member of the Croatian Parliament for the first time: besides Roma minority, Mr Nazif Memedi also represents Austrian, Bulgarian, German, Jewish, Polish, Romanian, Ruthenian, Turkish, Ukrainian and Vlach national minorities.

15 The Law on Education in Languages and Scripts of National Minorities, Official Gazette 51/00, 56/00; The Law on the Use of Languages and Scripts of National Minorities, Official Gazette 51/00, 56/00. 
communities. ${ }^{16}$ The tools used for the protection of a minority's culture and identity comprise a number of fields, such as education, minority media, the right for documents and scripts in a minority language, the free use of minority language and script in private, public and official spheres, among others.

The Constitution of the Republic of Croatia (2001) defines the Croatian language as the official language of Croatia; however, it enables the official use of minority languages in certain regional and local communities. ${ }^{17}$ The Constitutional Law (2002), dedicated specifically to national minorities, elaborates the freedom to use minority languages in private, public and official spheres. ${ }^{18}$ The official use of a minority language is territorially restricted - this right is exclusively enforced in local and regional authorities where a minority community makes up more than a third of the population. ${ }^{19}$ The Law on the Use of Languages and Scripts of National Minorities (2000) regulates the equal position of minority languages before municipal, city, and county administrative bodies, as well as before judicial bodies. ${ }^{20}$ The members of the Serbian minority community, as members of the largest minority community in Croatia, realize these rights in twenty-one units of local authorities, in which they comprise more than one third of the population. ${ }^{21}$ The members of minority communities lack an interest for the implementation of administrative procedures in the minority language, with the exception of the members of the Italian national minority. The issue of the use of minority language before judicial or administrative bodies should be primarily understood as a right of a practical approach before these bodies, and not as an instrument of the protection of minority identity. ${ }^{22}$

An important step to stimulate the cultural and political development of a minority is the possibility to have bilingual signs in many languages in areas where they are most represented. This regulation targets primarily the original names of towns, but also the freedom of appointing names of streets, squares and institutions after prominent people and events, which are closely connected to the minorities. ${ }^{23}$ A certain amount of those within the minority communities have a legal prerogative to use this right. Certain difficulties in implementing this right formerly occurred in areas in which international relations were undermined due to the direct war-related events during the 1990s and as such were not

16 The Constitutional Law on the Rights of National Minorities, Official Gazette 155/02, Art. 7, Art. 9-13.

17 The Constitution of Republic of Croatia, Official Gazette 41/01, 55/01, Art. 12.

18 The Constitutional Law on Rights of National Minorities, Official Gazette 155/02, Art. 07, Art. 10, Art. 12.

19 The Constitutional Law on Rights of National Minorities, Official Gazette 155/02, Art. 12.

20 The Law on the Use of Languages and Scripts of National Minorities, Official Gazette 51/00, 56/00

21 More in: The Report on the implementation of the Constitutional Law on the rights of the national minorities in the Republic of Croatia and the consumption of the budgetary means allocated for national minorities for 2003-2004, Government of the Republic of Croatia, Zagreb, 2006, p. 7

22 More in: Bandov, Goran: The Protection of Mother Tongue of National and Ethnic Minority Communities in the Republic of Croatia, Sapientia University, Cluj, 2010.

http://kv.sapientia.ro/uploads/rendezvenyek/mineureg/abstract_goran_ bandov.pdf (12.04.2011)

23 The Constitutional Law on Rights of National Minorities, Official Gazette 155/02, Art. 13 rebuilt properly; however, today no significant difficulties in implementing this regulation have been detected. ${ }^{24}$

Members of national minorities have the right to an education in their language and script. ${ }^{25}$ The education for minorities is implemented in preschool, elementary and high school institutions and in the system of summer and winter schools. The educational plan and program mirrors the plan and program that is followed in non-minority schools. The basic difference lies in the language and script used. The objective and subjective circumstances of individual members in a minority differ a lot, especially from one minority to another, but also within a minority, depending on the different areas in Croatia. Croatia developed three models and forms of minority education, as follows:

Model A: Implementing education in the language and script of a national minority, but with an obligation to learn the Croatian language.

Model B: System of bilingual education, where the curriculum is executed in the minority language (humanities and social sciences) and in Croatian (natural science).

Model C: Implementing Croatian education, but with an additional module in the curriculum, where the culture of the national minority is taught five hours per week (composed of the minority language, literature, history, geography, visual arts and culture).

Within the education system there is significant discrimination, however. The Constitutional Law (2002), among others, guarantees a more favourable condition towards the education for the minority than towards the establishment of a general education system. ${ }^{26}$ Each minority can form different models in different areas of Croatia and at different levels of education. When there are not enough people within a certain district, the state is only obliged to organize transport to the nearest minority school if the student does not have to travel too far. However, only a small number of minority communities were interested to form their own minority education institutions according to Models A and B. Those minority communities who did decide for Models A and B are more numerous in terms of their members, having a high congregation in particular areas. Model A has been chosen by the Czech, Serbian, Italian, Bosnian and Hungarian minority and Model B has been chosen by the Czech and Hungarian minority. ${ }^{27}$ Most of minority groups are educated in a regular system of education, utilizing Model C or/and various forms of additional education, such

24 More in: Bandov, Goran: The Protection of Mother Tongue of National and Ethnic Minority Communities in the Republic of Croatia, Sapientia University, Cluj, 2010

http://kv.sapientia.ro/uploads/rendezvenyek/mineureg/abstract_goran_ bandov.pdf (12.04.2011)

25 The Constitutional Law on the Rights of National Minorities, Official Gazette 155/02, Art. 11.

26 The Constitutional Law on the Rights of National Minorities, Official Gazette 155/02, Art. 11; The Law on Education in Languages and Scripts of National Minorities, Official Gazette 51/00, 56/00, Art. 3.

27 More in: Bandov, Goran: The Protection of Mother Tongue of National and Ethnic Minority Communities in the Republic of Croatia, Sapientia University, Cluj, 2010.

http://kv.sapientia.ro/uploads/rendezvenyek/mineureg/abstract_goran bandov.pdf (12.04.2011) 
as summer and winter schools. Model C was chosen by the Slovakian, Czech, Hungarian, Macedonian, Ukrainian, Ruthenian, German, and Austrian minority. ${ }^{28}$

Having minority languages in media is not only vital to protect their identity but also to enable constitutional rights on free access to information. There are a number of people who do not fully understand the Croatian language, and not providing information in their language would be a violation of the constitutional right to information. According to the Constitutional Law (2002), the members of national minorities can establish associations, foundations or institutions for the purposes of providing public or cultural information and publishing or organizing academic activities to promote, preserve or develop their national identity. ${ }^{29}$ According to their capabilities, the financing of these institutions is the obligation of the state, or the local and regional authorities. Since the provisions of the Constitutional Law (2002) have been implemented, most of the minority communities are generating rich publishing activities and facilitating wider access to information in the minority language. In this area there are no obstructions, and activities are financially supported by all government levels. ${ }^{30}$

\subsection{Political Level of Minority Rights}

Minorities' political representation on all levels of the decision making process is important for the democratic development of the society. It was not implemented in the socialist Yugoslavia because it was a classic system of a one-party state. The Yugoslav Constitution (1963) stated that the minorities could associate in order to protect their identity in a more distinct way. ${ }^{31}$ However, it was only after Croatian independence that members of minorities could associate in political associations. Since there was a rule that only electoral lists with a minimum of $3 \%$ votes enter the parliament in Croatia at the beginning of 1990s. The rule changed in the case of minority groups based on demand of one of the Serbian parties (Srpska narodna stranka - SNS) and was valid for non-minority groups. Based on the decision of the Constitutional Court, the Republic of Croatia has been attempting to counter discrimination by constituting minority electoral areas. ${ }^{32}$ This was an obvious sign for the members of the Serbian national minority that they would be granted free participation within the Croatian government

Important progress in this direction was the Constitutional Law (2002), which strongly supported links between minority

28 More in: Bandov, Goran: The Protection of Mother Tongue of National and Ethnic Minority Communities in the Republic of Croatia, Sapientia University, Cluj, 2010.

http://kv.sapientia.ro/uploads/rendezvenyek/mineureg/abstract_goran_ bandov.pdf (12.04.2011)

29 The Constitutional Law on the Rights of National Minorities, Official Gazette 155/02, Art. 17-18.

30 More in: The Report on the implementation of the Constitutional Law on the rights of the national minorities in the Republic of Croatia and the consumption of the budgetary means allocated in 2006 for national minorities, Office for national minorities, Government of the Republic of Croatia, Zagreb, 2007, p. 11.

31 The Constitution of the Socialist Federative Republic of Yugoslavia, SL SFRJ, Beograd, 1963.

32 The Decision of the Constitutional Court of the Republic of Croatia, U-VII233/1992, Zagreb, 6.8.1992. groups and their 'kin state' in order to ensure the promotion of their common ethnic, national, cultural and linguistic identity. Minority communities enjoy the right to form their own political associations and ethnic (and national) parties, and a range of autonomously established associations and institutions have been set up. ${ }^{33}$ The Constitutional Law (2002) guarantees members of national minorities the right to at least 8 members of Parliament (MPs) in the Parliament of the Republic of Croatia. ${ }^{34}$ Members of the Serbian national minority are guaranteed three MP seats. Members of national minorities that have less than 1,5\% in the population of Croatia have the right to elect at least four MPs as representatives of a national minority. The electoral system is highly complex and does not discriminate against larger ethnic (national) minority groups. According to this, minorities are guaranteed three members of the Serbian national minority - one each for Italian and Hungarian minorities, while the Czech and Slovak compete for one seat. Other minorities compete for two seats in separate groups. Thus, one MP is voted for by Albanian, Bosnian, Macedonian, Montenegrinian and Slovenian national minorities, and one joint representative is voted for by the members of the Austrian, Bulgarian, German, Jewish, Polish, Romanian, Ruthenian, Turkish, Ukrainian and Vlach minorities.

The changes and amendments to the Constitutional Law that occurred in 2010 were very important because they encouraged positive discrimination of minorities in political participation. ${ }^{35}$ Along with the right to vote for the minority list, the national minorities that participate with less than $1.5 \%$ in the population of Croatia are guaranteed the right to participate simultaneously in general and minority elections. Before this amendment, the members of minority groups had to decide at the voting place on their candidate. Due to this amendment, all members of ethnic and national minorities (except Serbian) have two votes at regular elections: one vote for the general list and the other for the representative of minorities. At the same time, the Croatian Constitutional Law (2002) guarantees members of national minorities the right to be represented in representative bodies of local and regional authorities. $^{36}$

The Constitutional Law (2002) introduced two new factors within the political level for the protection for those on the Board of National Minorities in local and regional units, and also for those on the Council for National Minorities at state level. On the local level, every minority with more than 200 members, and on the regional level every minority with more than $1.5 \%$, may be in the Board of National Minority. ${ }^{37}$ The Board has primarily a counseling role and can, among others, suggest authorities to improve positions concerning

33 The Constitutional Law on the Rights of National Minorities, Official Gazette 155/02, Art. 15, Art. 19.

34 The Constitutional Law on the Rights of National Minorities, Official Gazette 155/02, Art. 19; The Constitutional Law on Changes and Amendments of the Constitutional Law on the Rights of National Minorities, Official Gazette, $80 / 10$.

35 The Constitutional Law on Changes and Amendments of the Constitutional Law on the Rights of National Minorities, Official Gazette, 80/10, Art. 1.

36 The Constitutional Law on the Rights of National Minorities, Official Gazette 155/02, Art. 20

37 The Constitutional Law on the Rights of National Minorities, Official Gazette $155 / 02$, Art. 24 
the national minority; propose candidates for office in state government and administration positions; and produce judgments and suggestions to radio and television stations on local and regional levels for national minorities or programmes that deal with minority issues. ${ }^{38}$

The Council for National Minorities has been established to improve participation of national minorities in public life of the Republic of Croatia. ${ }^{39}$ The Council has numerous rights, such as to suggest state bodies to discuss issues of importance concerning national minorities; to give opinions and suggestions about treatment of minority issues in public media programs; and to suggest business, social and other measures in areas traditionally or dominantly populated by members of national minorities in order to preserve their existence in those areas. ${ }^{40}$ The state has additionally strengthened the role of Councils by granting them the right to distribute financial support to minority associations. It should be stressed that all members of Councils are members of minorities, coming from all walks of life, from politics to science and cultural institutions.

\subsection{Socio-economic Level of Minority Protection}

The most sensitive area of minority protection is the segment of social and economic rights. The rights are very sensitive in the entire Croatian society and the members of minorities are no exception. However, minority members are in an even more unfavourable situation due to the fact that they do not belong to the majority group. Croatia bound itself to the "Charter on the Rights of Serbs and Other Nationalities in the Republic of Croatia" to ensure economic and social development of minorities in order to preserve their minority identity. ${ }^{41}$ In a number of later constitutional and legal regulations, Croatia additionally bound itself to establish social and economic minority protection. ${ }^{42}$ According to this, Croatia, among others, obliges itself to employ the proportional number of minority members to their percentage in population in the bodies of state, regional and local bodies. ${ }^{43}$ These stipulations did not take hold completely in 1990s, especially in areas of local and regional authorities.

The Constitutional Law (2002) guarantees members of national minorities representation within the state administration, also with local and regional authorities, proportional to their participation in population. ${ }^{44}$ This segment is to counter discrimination, and any vacancy in the state or public administration gives preference to members of ethnic and national minority to fulfill the number of minorities

38 The Constitutional Law on the Rights of National Minorities, Official Gazette $155 / 02$, Art. 30.

39 The Constitutional Law on the Rights of National Minorities, Official Gazette 155/02, Art. 35-36.

40 The Constitutional Law on the Rights of National Minorities, Official Gazette 155/02, Art. 35.

41 The Charter on the Rights of Serbs and Other Nationalities in the Republic of Croatia, Official Gazette 31/91, Nr. V.

42 The Law on the System of State Administration, Official Gazette 75/93, 48/99, 15/00, 127/00, 59/01, 190/03, 199/03; The Constitutional Law on the Rights of National Minorities, Official Gazette 155/02, Art. 22.

43 The Law on the System of State Administration, Official Gazette 75/93, Art. 8.

44 The Constitutional Law on the Rights of National Minorities, Official Gazette 155/02, Art. 22. proportional to their population in Croatia. According to the analysis of the implementation of Article 22 of the Constitutional Law (2002), conducted in 2006 by the Serbian Democratic Forum, some irregularities and flaws were found in the implementation of the Constitutional law. ${ }^{45}$

The state authorities spotted flaws in implementation in local and regional districts. ${ }^{46}$ Local and regional authorities explained implementation was not possible due to the following reasons: there was no list of employers according to national affiliation, financial problems and no new employment as of $2002 .{ }^{47}$ The state warned local and regional units about their obligation to respect Article 22 of the Constitutional Law and their obligation to incorporate the stipulations in statutes of the units. The units that did not follow this warning were dissolved. Due to this, after 2008 no violations of the article had been recorded all those units obliged to incorporate the stipulation into the statute of their unit did so.

Affirmative development was significantly supported by the close political relationship with the Croatian Democratic Union (HDZ), which has been the ruling political party in Croatia since 2003 with the support of minority parties and minority MPs in the Croatian Parliament. HDZ signed a coalition agreement in 2008 with the Independent Democratic Serbian Party (SDSS) as leading party of Croatian Serbs. In addition to the constitution and various laws, the agreement guaranteed complete implementation of Article 22 of the Constitutional Law (2002). ${ }^{48}$ Additional coalition relationships were signed with other representatives of minorities, in which HDZ committed itself to ultimate respect of the Constitutional Law (2002). Since then the leading position of HDZ has depended upon votes from minorities' representatives since 2003. The position of the minorities in the country has become stronger, both in social and economic, as well as in other fields of protecting minority rights.

\section{Conclusion}

Since Croatia's acceptance to a full European integration was conditioned by the implementation of protecting minority rights, Croatia did its best to fulfill this requirement. During the 1990s there were many challenges in implementing minority rights, especially concerning the Serbian national minority. This was mainly due to ethnic and political escalation at the time. Other minority rights, except for those of the Roma, were not violated.

An actual breakthrough for minority rights occurred during the democratic changes in 2000s with enacting the Constitutional

45 The Research on implementation of Article 22 of the Constitutional Law on the Rights of National Minorities, Serbian Democratic Forum (SDF), Zagreb, September, 2006.

46 The Report on the implementation of the Constitutional Law on the rights of the national minorities in the Republic of Croatia and the consumption of the budgetary means allocated in 2006 for national minorities, Office for national minorities, Government of the Republic of Croatia, Zagreb, 2007, p. 39.

47 The Report on the implementation of the Constitutional Law on the rights of the national minorities in the Republic of Croatia and the consumption of the budgetary means allocated in 2006 for national minorities, Office for national minorities, Government of the Republic of Croatia, Zagreb, 2007, p. 40.

48 The Agreement between HDZ and SDSS on cooperation in the Croatian government and Croatian Parliament, Zagreb, January 10, 2008. 
Law on the Rights of National Minorities (2002). It fully covered all levels of minority protection, from the fundamental, cultural and political to the social and economic one. The biggest challenge was implementing legal stipulations, especially on local and regional levels. But after 2008, when the state executed its direct influence upon bodies of local and regional units, such as dissolution of assemblies and mayors, the stipulations of the Constitutional Law were incorporated in statutes of the units and entirely implemented. An enormous contribution has been achieved by a positive atmosphere around political elites and all national groups in Croatia, as well as a joint participation in authority of HDZ, SDSS and majority MPs of national minorities since 2003.

Table: Population of Croatia by nationality, the 2001 census. ${ }^{49}$

\begin{tabular}{|c|c|c|}
\hline $\begin{array}{l}\text { Population by nationality } \\
\text { (2001) }\end{array}$ & $\begin{array}{l}\text { Number of } \\
\text { citizens }\end{array}$ & $\begin{array}{l}\text { Percent } \\
(\%)\end{array}$ \\
\hline In total & $4,437,460$ & 100.00 \\
\hline Croats & $3,977,171$ & 89.63 \\
\hline Serbs & 201,631 & 4.54 \\
\hline Yugoslavs & 127 & 0.00 \\
\hline Bosniacs & 20,755 & 0.47 \\
\hline Italians & 19,636 & 0.44 \\
\hline Hungarians & 16,595 & 0.37 \\
\hline Albanians & 15,032 & 0.34 \\
\hline Slovenians & 13,173 & 0.30 \\
\hline Czechs & 10,510 & 0.24 \\
\hline Roma & 9,463 & 0.21 \\
\hline Montenegrins & 4,926 & 0.11 \\
\hline Slovakians & 4,712 & 0.11 \\
\hline Macedonians & 4,270 & 0.10 \\
\hline Germans & 2,902 & 0.07 \\
\hline Ruthenians & 2,337 & 0.05 \\
\hline Ukrainians & 1,977 & 0.04 \\
\hline Russians & 906 & 0.02 \\
\hline Jews & 576 & 0.01 \\
\hline Polish & 567 & 0.01 \\
\hline Romanians & 475 & 0.01 \\
\hline Bulgarians & 331 & 0.00 \\
\hline Turks & 300 & 0.00 \\
\hline Austrians & 247 & 0.00 \\
\hline Vlachs & 12 & 0.00 \\
\hline Others & 21,801 & 0.49 \\
\hline \multicolumn{3}{|l|}{$\begin{array}{l}\text { Have not declared their } \\
\text { national affiliation }\end{array}$} \\
\hline In total & 79,828 & 1.80 \\
\hline Regional affiliation & 9,302 & 0.21 \\
\hline Unknown & 17,975 & 0.41 \\
\hline
\end{tabular}

49 Data provided by the Central Bureau of Statistics - data on the number of members of national minorities in Croatia. http://www.dzs.hr. (25.05.2010)

\section{Staat ist nicht gleich Staat}

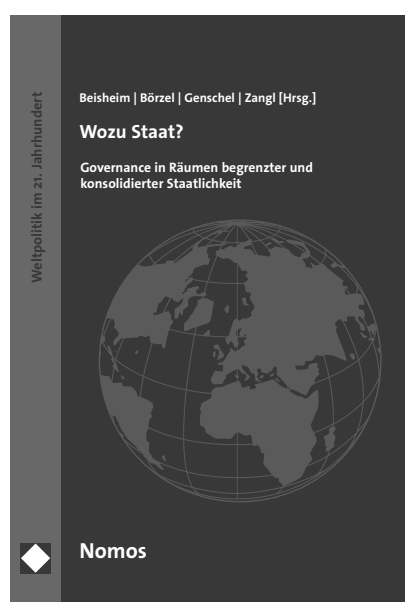

\section{Wozu Staat?}

Governance in Räumen begrenzter und konsolidierter Staatlichkeit

Herausgegeben von Marianne Beisheim, Tanja A. Börzel, Philipp Genschel und Bernhard Zangl

2011, 279 S., brosch., 34,- $€$, ISBN 978-3-8329-6971-4

Erscheint ca. Oktober 2011

nomos-shop.de/14070

Welche Governance-Leistungen erbringt der Staat in den Politikfeldern Sicherheit, Gesundheit, Umwelt und Finanzmärkte? Welche Governance-Beiträge kommen von nicht-staatlichen Akteuren? Welche Beziehungsund Konfliktmuster dominieren?

Der Band zeigt erstens, dass der Staat in keinem der untersuchten Fälle das Governance-Monopol hält, sondern immer auch nicht-staatliche Akteure GovernanceFunktionen ausüben. Zweitens finden wir ausgeprägte Unterschiede zwischen den Räumen: Während sich in Räumen konsolidierter Staatlichkeit tendenziell eine vom Staat moderierte Arbeitsteilung mit nicht-staatlichen Governance-Akteuren einstellt, ist das Verhältnis in Räumen begrenzter Staatlichkeit durch Konkurrenz und fehlende Hierarchie gekennzeichnet. Drittens unterscheidet sich das Zusammenspiel staatlicher und nicht-staatlicher Akteure kaum zwischen Politikfeldern.

Die Analyse mündet in der Unterscheidung von vier idealtypischen Governance-Konstellationen staatlicher und nicht-staatlicher Akteure.

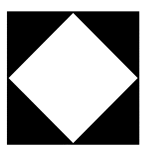

Nomos

Bitte bestellen Sie im Buchhandel oder versandkostenfrei unter $\triangleright$ www.nomos-shop.de 